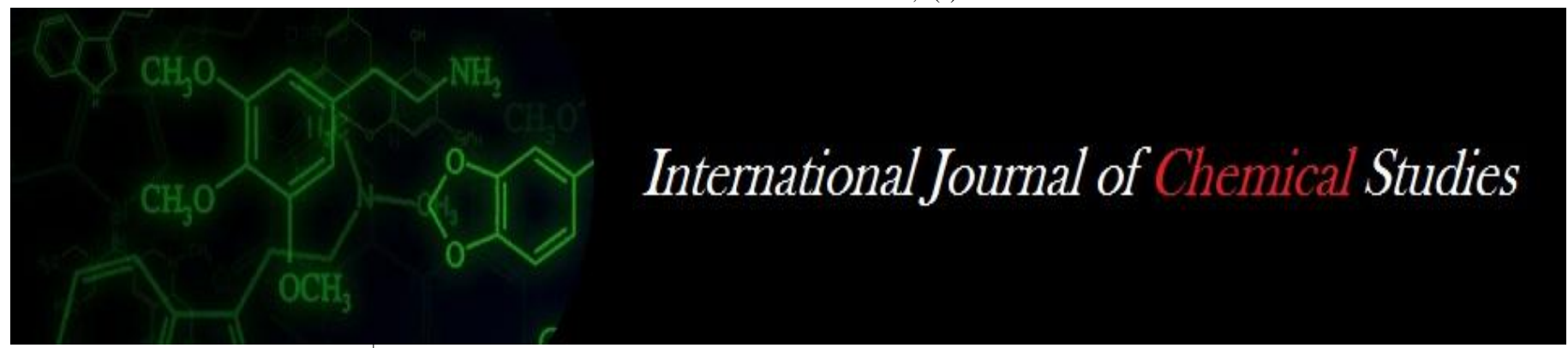

P-ISSN: 2349-8528

E-ISSN: 2321-4902

www.chemijournal.com

IJCS 2020; 8(6): 2223-2227

(C) 2020 IJCS

Received: 18-08-2020

Accepted: 22-11-2020

Shubham

Department of Soil Science and Water management, Dr. YSP UHF Nauni, Solan, Himachal Pradesh, India

Sharma Uday

Department of Soil Science and Water management, Dr. YSP UHF Nauni, Solan, Himachal Pradesh, India

Corresponding Author: Shubham

Department of Soil Science and Water management, Dr. YSP UHF Nauni, Solan, Himachal Pradesh, India

\section{Long term effect of different plant based nitrification inhibitors and calcium carbide on total soluble solids (TSS), ascorbic acid and protein content of cauliflower (Brassica oleracea var. Botrytis L)}

\author{
Shubham and Sharma Uday
}

DOI: https://doi.org/10.22271/chemi.2020.v8.i6af.11104

\begin{abstract}
The study was devoted to assess the effect of different nitrification plant based nitrification inhibitors and chemical inhibitor on total soluble solids (TSS), ascorbic acid and proteins content of cauliflower. The study was conducted as a field experimental with eight treatment combinations replicated thrice in completely randomized block design during rabi season 2018-19 and 2019-20. Different treatments combinations viz. melia fruit powder, pomegranate rind powder, commercial neem cake, calcium carbide $\left(\mathrm{CaC}_{2}\right)$ and absolute control were incorporated in the study. The results revealed that during both the years of study maximum TSS values of 6.70 and $6.83{ }^{\circ}$ brix were recorded in MF@ $20 \mathrm{~g} \mathrm{~kg}^{-1}$ soil and NC @ $20 \mathrm{~g} \mathrm{~kg}^{-1}$ soil, respectively. While the least TSS value recorded in control treatment. Maximum ascorbic acid was attributed to NC@ $20 \mathrm{~g} \mathrm{~kg}^{-1}$ soil i.e. 74.43 and $76.19 \mathrm{mg} 100 \mathrm{~g}^{-1}$ during 2018-19 and

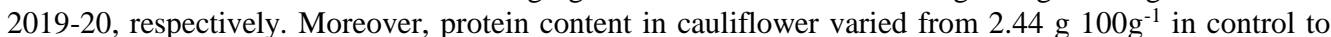

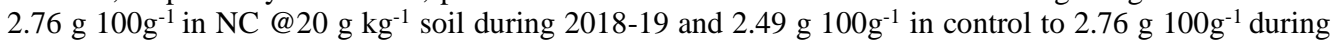
2019-20 in the same treatment. Application of plant based nitrification inhibitor neem cake@ $20 \mathrm{~g} \mathrm{~kg}^{-1}$ soil with recommended dose of NPK and farmyard manure was found effective over the chemical inhibitor and therefore improved the quality of cauliflower.
\end{abstract}

Keywords: nitrification inhibitors, nitrogen economy, nutrient management, sustainable agriculture

\section{Introduction}

Application of nitrogenous fertilizers has been considered as the major factor for increased agricultural productivity world-wide since last few decades. Nitrogen is regarded as a most important essential nutrient which controls the diversity and functioning of many terrestrial, freshwater and marine ecosystems. However, huge application of nitrogenous fertilizers are being practiced in the developing countries causing hazards like land degradation. Being a highly mobile and dynamic element nitrogen losses occurs through different ways i.e. $\mathrm{NO}_{3}{ }^{-}$ leaching, denitrification, runoff, $\mathrm{NH}_{3}$ volatilization, gaseous emissions of $\mathrm{N}_{2} \mathrm{O}$ and $\mathrm{NO}$ to the atmosphere (Zaman et al., 2009) ${ }^{[23]}$. The losses from the fertilizers have long term adverse effects on the ecology and environment by means of eutrophication, losses in aquatic biodiversity and increased $\mathrm{N}_{2} \mathrm{O}$ emissions (Warneke et al., 2011) ${ }^{[22]}$. Nitrogen metabolism is primarily a microbially mediated process. Some microorganisms play an important role in improving the fertility of soil by metabolizing the $\mathrm{N}$ which is not taken up by the plants.

At present, heavy inputs of $\mathrm{N}$ fertilizer are being practiced to sustain the productivity, as the naturally fixed $\mathrm{N}$ is rarely enough for high production systems (Dinnes et al., 2002; Subbarao et al., 2006; Abbasi et al., 2012) [5, 20, 1]. Therefore, for lowering the pollution hazards to environment, efficiency of nitrogenous fertilizers needs to be improved. Adoption of nitrification inhibitors could prove to be a boon for improving $\mathrm{N}$ use efficiency. Nitrification inhibitors can reduce $\mathrm{N}$ losses by reducing the rate of nitrification through their action in inhibiting the nitrifying bacteria and thus improving the uptake rate of plant for ammonium $\left(\mathrm{NH}_{4}{ }^{+}\right)$. The nitrification inhibitors play an important role in increasing the yields and lower down the $\mathrm{N}_{2} \mathrm{O}$ emissions (Zhang et al., 2015) ${ }^{[24]}$. 
Nitrification is two steps natural process occurring in the soil in which ammonium is converted into nitrite and further to nitrate form of nitrogen. The Nitrosomonas spp. of soil bacteria extract the energy from ammonium while converting it to nitrite form. Furthermore, another group of bacteria i.e. Nitrobacter spp. convert the nitrite form into nitrate. Both types of bacteria are commonly found in soil and determine the overall rate of nitrate production. Nitrification inhibitors are generally the compounds which depress the activity of Nitrosomonas bacteria and ultimately delay the nitrate production from ammonium. These nitrification inhibitors fasten their activity when provided with adequate soil moisture and soil type. Nitrification inhibitors work more effectively in sandy soils or soils which are low in organic matter and exposed to low temperatures. Retarding the nitrification process results in maintaining appreciable higher amounts of inorganic $\mathrm{N}$ in the ammonium form in soil and hence less losses and movement of nitrogen into the soil system. There are several compounds which are commercially recognized as nitrification inhibitors, the most commonly used are 2-chloro-6-(trichloromethyl)-pyridine (Nitrapyrin), dicycandiamide (DCD), 3,4-dimethylpyrazole phosphate (DMPP), neem cake and Melia azedarach (McCarty 1999; Abbasi et al., 2003; Fangueiro et al., 2009; Khalil et al., 2009; Zaman et al., 2009; Souri 2010; Pereira et al., 2010) [15, 3, 7, 10, $23,19,17]$. Besides these chemical origin compounds, nitrification inhibitory properties of some inexpensive compounds like calcium carbide $\left(\mathrm{CaC}_{2}\right)$ and several plants materials wastes like Karanji (Pongamia glabra), Neem (Azadirachta indica), Dharek (Melia azedarach. L) and tea
(Camellia sinensis) have been reported by many researchers (Freney et al., 2000, Kiran and Patra 2003; Majumdar 2002; Moreno et al., 2010 ; Abbasi et al., 2011) ${ }^{[8,11,12,14,2]}$.

The ease of using the nitrification inhibitors depends on its easy availability and lower input cost. Dharek (Melia azedarach. L) is a deciduous tree belonging to the family Meliaceae. Taxonomically, this plant resembles neem which mostly grows in the tropical to sub temperate regions of Europe and Northern America. Leaves and fruits of melia possess the nitrification inhibitor properties and hence could be used as an amendement. Incorporation of melia derivatives into the soil has been reported to increase the soil fertility (Toselli et al., 2010) [21]. In India around 80,000 tons of oil and 3,30,000 tons of neem cake is being prepared from 14 million growing trees as reported in a study (Nicoletti et al., 2012). Similarly, wild pomegranate (daaru) is a very common plant in the mid- Himalayan region and its rind is also supposed to have properties which can help in the inhibition of nitrification and their non-economical portions can be effectively used as nitrification inhibitors.

\section{Material and methods}

The study was conducted as field experiments during 2018-19 and 2019-20 at the experimental farm of Department of Soil Science and Water Management Dr. YSP UHF Nauni, Solan (H.P.). The experiment was laid out in a randomized block design with eight treatments replicated thrice. The following treatments were incorporated in the study to compel on cauliflower.

Treatments were laid in randomized block design

\begin{tabular}{|c|c|}
\hline Serial No. & Treatments \\
\hline $\mathrm{T}_{1}$ & Powdered pomegranate rind @ $10 \mathrm{~g} \mathrm{~kg}^{-1}$ of soil \\
\hline $\mathrm{T}_{2}$ & Powdered pomegranate rind @ $20 \mathrm{~g} \mathrm{~kg}^{-1}$ of soil \\
\hline $\mathrm{T}_{3}$ & Powdered melia fruits @ $10 \mathrm{~g} \mathrm{~kg}^{-1}$ of soil \\
\hline $\mathrm{T}_{4}$ & Powdered melia fruits @ $20 \mathrm{~g} \mathrm{~kg}^{-1}$ of soil \\
\hline $\mathrm{T}_{5}$ & Commercial neem cake @ $10 \mathrm{~g} \mathrm{Kg}^{-1}$ of soil \\
\hline $\mathrm{T}_{6}$ & Commercial neem cake @ $20 \mathrm{~g} \mathrm{~kg}^{-1}$ of soil \\
\hline $\mathrm{T}_{7}$ & Calcium carbide $($ CaC 2$) @ 15 \mathrm{~g} \mathrm{~kg}^{-1}$ of soil \\
\hline $\mathrm{T}_{8}$ & Absolute control \\
\hline
\end{tabular}

Treatments were laid in randomized block design with plot size of $6 \mathrm{~m}^{2}(3 \mathrm{~m} \times 2 \mathrm{~m})$ and the seedlings were transplanted at a planting distance of $60 \mathrm{~cm} \times 45 \mathrm{~cm}$. All the treatments were given recommended dose of NPK (125:76:72) except absolute control. FYM was also incorporated @ $250 \mathrm{q} \mathrm{ha}^{-1}$ in all treatments except control. Plant derivatives rates were calculated and applied as per the treatments.

\section{Result and discussion \\ Total soluble solids (TSS)}

The data presented in table (1) showed that the maximum TSS (6.70 ${ }^{\circ}$ brix) during 2018-19 was recorded in the treatment $\mathrm{T}_{4}$ and $\mathrm{T}_{6}$ which at par with $6.58^{\circ}$ brix in $\mathrm{T}_{7}$ i.e. $\mathrm{CaC}_{2} @ 15 \mathrm{~g} \mathrm{~kg}^{-}$

1 soil. The minimum TSS of $6.33^{\circ}$ brix was recorded in control $\left(\mathrm{T}_{8}\right)$. During the year 2019-20 the maximum TSS of $6.83^{\circ}$ brix followed by $6.65^{\circ}$ brix were recorded in $\mathrm{T}_{4}$ and $\mathrm{T}_{6}$, respectively, while the minimum was again in absolute control. The pooled data analysis revealed a maximum TSS of $6.76^{\circ}$ brix in $\mathrm{T}_{4}$ but was not statistically significant to all other treatments. The interaction $\mathrm{T} \times \mathrm{Y}$ showed that a maximum TSS of $6.83^{\circ}$ brix was in $\mathrm{T}_{4}$ during 2019-20 which was at par with $\mathrm{T}_{4}, \mathrm{~T}_{6}$ in 2018 and $\mathrm{T}_{6}$ and $\mathrm{T}_{7}$ in the year 201920. Thus, the curd obtained under the soil treatment with melia fruit powder@20 $\mathrm{g} \mathrm{kg}^{-1}$ soil $\left(\mathrm{T}_{4}\right)$ had the maximum TSS values. Singh et al, 2018 also reported that better nutrition (nitrogen management) results in improved levels of carbohydrates and other quality parameters of cauliflower curd through enzymatic activity. 
Table 1: Effect of nitrification inhibitors on TSS and ascorbic acid in cauliflower

\begin{tabular}{|c|c|c|c|c|c|c|}
\hline \multirow{2}{*}{ Treatment * } & \multicolumn{3}{|c|}{ TSS $\left({ }^{\circ}\right.$ brix $)$} & \multicolumn{3}{|c|}{ Ascorbic acid (mg $\left.100 \mathrm{~g}^{-1}\right)$} \\
\hline & 2018-19 & 2019-20 & Pooled & 2018-19 & 2019-20 & Pooled \\
\hline $\mathrm{T}_{1}$ : PR @ $10 \mathrm{~g} \mathrm{~kg}^{-1}$ soil & 6.40 & 6.44 & 6.42 & 66.82 & 67.51 & 67.17 \\
\hline $\mathrm{T}_{2}$ :PR @ $20 \mathrm{~g} \mathrm{~kg}^{-1}$ soil & 6.50 & 6.35 & 6.43 & 68.73 & 69.98 & 69.35 \\
\hline $\mathrm{T}_{3}: \mathrm{MF} @ 10 \mathrm{~g} \mathrm{~kg}^{-1}$ soil & 6.42 & 6.42 & 6.42 & 66.77 & 69.13 & 67.95 \\
\hline $\mathrm{T}_{4}: \mathrm{MF} @ 20 \mathrm{~g} \mathrm{~kg}^{-1}$ soil & 6.70 & 6.83 & 6.76 & 72.26 & 73.41 & 72.83 \\
\hline T5: NC @ $10 \mathrm{~g} \mathrm{~kg}^{-1}$ soil & 6.45 & 6.42 & 6.44 & 69.14 & 70.86 & 70.00 \\
\hline $\mathrm{T}_{6}: \mathrm{NC} @ 20 \mathrm{~g} \mathrm{~kg}^{-1}$ soil & 6.70 & 6.65 & 6.68 & 74.43 & 76.19 & 75.31 \\
\hline $\mathrm{T}_{7}: \mathrm{CaC}_{2} @ 15 \mathrm{~g} \mathrm{~kg}^{-1}$ soil & 6.58 & 6.62 & 6.60 & 71.26 & 72.64 & 71.95 \\
\hline T8: Absolute control & 6.33 & 6.24 & 6.29 & 58.41 & 59.83 & 59.12 \\
\hline Mean & 6.47 & 6.54 & & 69.26 & 69.15 & \\
\hline $\mathrm{CD}(0.05)$ & 0.14 & 0.34 & & 2.05 & 3.78 & \\
\hline $\mathrm{T}$ & \multicolumn{3}{|c|}{ NS } & \multicolumn{3}{|c|}{1.99} \\
\hline $\mathrm{Y}$ & \multicolumn{3}{|c|}{ NS } & \multicolumn{3}{|c|}{ NS } \\
\hline $\mathrm{T} \times \mathrm{Y}$ & \multicolumn{3}{|c|}{0.24} & \multicolumn{3}{|c|}{2.81} \\
\hline
\end{tabular}

* RD of NPK were applied uniformly to all the treatments except $\mathrm{T} 8$ (control)

$\mathrm{PR}=$ Pomegranate Rind MF = Melia Fruits $\mathrm{NC}=$ Neem Cake

\section{Ascorbic acid}

The data presented in table (1) revealed that during 2018-19 the maximum ascorbic acid content $\left(74.43 \mathrm{mg} 100 \mathrm{~g}^{-1}\right)$ was recorded in the treatment $\mathrm{T}_{6}$ comprising of the application of neem cake@20 g kg-1 soil was followed by $72.26 \mathrm{mg} 100 \mathrm{~g}^{-1}$ in $\mathrm{T}_{4}$ i.e. MF @ $20 \mathrm{~g} \mathrm{~kg}^{-1}$ soil.

The minimum ascorbic acid of $58.41 \mathrm{mg} 100 \mathrm{~g}^{-1}$ was in $\mathrm{T}_{8}$ (control). During the year 2019-20 the maximum ascorbic acid of $76.19 \mathrm{mg} 100 \mathrm{~g}^{-1}$ was again recorded in $\mathrm{T}_{6}$ which was at par with $T_{4}$ and $T_{7}$, while the minimum remained in absolute control.

The pooled data analysis revealed a maximum ascorbic acid of $75.31 \mathrm{mg} 100 \mathrm{~g}^{-1}$ in $\mathrm{T}_{6}$ which was statistically superior to all other treatments and minimum was in $\mathrm{T}_{8}$ (control). The interaction $\mathrm{T} \times \mathrm{Y}$ showed that maximum ascorbic acid of 76.19 mg $100 \mathrm{~g}^{-1}$ was in $\mathrm{T}_{6}$ during 2019-20 which was at par with $74.43 \mathrm{mg} 100 \mathrm{~g}^{-1}$ in the same treatment during 2018-19, and $73.41 \mathrm{mg}^{100 \mathrm{~g}^{-1}}$ in $\mathrm{T}_{4}$ during 2019-20. Amongst pomegranate and melia powders, the application of melia fruit powder @ $20 \mathrm{~g} \mathrm{~kg}^{-1}$ soil $\left(\mathrm{T}_{4}\right)$ was superior, but statistically lower than the maximum values. These results are also supported by the findings of Oyinlola et al., (2017) ${ }^{[16]}$ who ascribed it to the changed soil conditions and plant nutrition.

\section{Proteins}

During 2018-19 the maximum protein content $\left(2.76{\left.\mathrm{~g} 100 \mathrm{~g}^{-1}\right)}^{-1}\right.$ was recorded in the treatment $\mathrm{T}_{6}$ comprising of the application of neem cake @ $20 \mathrm{~g} \mathrm{~kg}^{-1}$ soil which was at par with $\mathrm{T}_{4}, \mathrm{~T}_{5}$ and $\mathrm{T}_{7}$ (Table 2). The minimum protein content of

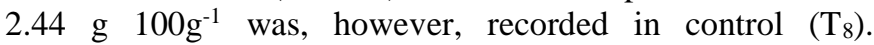
Similarly in the year 2019-20 the maximum protein content of

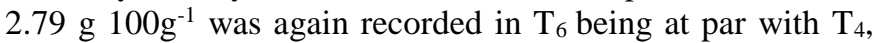
$\mathrm{T}_{5}$ and $\mathrm{T}_{7}$, while the minimum was again in absolute control. The pooled data analysis revealed a maximum protein content

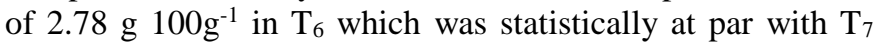
but superior over all the other treatments. The average protein

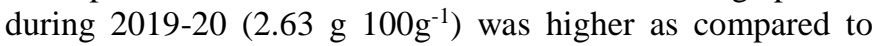
that in 2018-19 (2.61 $\mathrm{g}^{\left.100 \mathrm{~g}^{-1}\right)}$ but statistically nonsignificant. The interaction $\mathrm{T} \times \mathrm{Y}$ showed a maximum protein

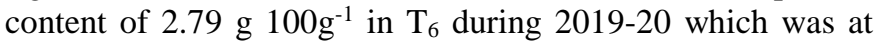
par with $\mathrm{T}_{4}, \mathrm{~T}_{5}, \mathrm{~T}_{6}$ and $\mathrm{T}_{7}$ in 2018-19 and $\mathrm{T}_{4}, \mathrm{~T}_{5}$ and $\mathrm{T}_{7}$ in 2019-20.

Table 2: Effect of plant derivatives on protein content in cauliflower

\begin{tabular}{|c|c|c|c|}
\hline \multirow{2}{*}{ Treatment * } & \multicolumn{3}{|c|}{ Protein $\left(\mathrm{g} \mathrm{100g}^{-1}\right)$} \\
\hline & 2018-19 & $2019-20$ & Pooled \\
\hline $\mathrm{T}_{1}$ : PR @ $10 \mathrm{~g} \mathrm{~kg}^{-1}$ soil & 2.55 & 2.56 & 2.56 \\
\hline $\mathrm{T}_{2}: \mathrm{PR} @ 20 \mathrm{~g} \mathrm{~kg}^{-1}$ soil & 2.58 & 2.58 & 2.58 \\
\hline $\mathrm{T}_{3}$ : MF @ $10 \mathrm{~g} \mathrm{~kg}^{-1}$ soil & 2.51 & 2.53 & 2.52 \\
\hline $\mathrm{T}_{4}: \mathrm{MF} @ 20 \mathrm{~g} \mathrm{~kg}^{-1}$ soil & 2.67 & 2.68 & 2.68 \\
\hline $\mathrm{T}_{5}: \mathrm{NC} @ 10 \mathrm{~g} \mathrm{~kg}^{-1}$ soil & 2.66 & 2.67 & 2.67 \\
\hline $\mathrm{T}_{6}: \mathrm{NC} @ 20 \mathrm{~g} \mathrm{~kg}^{-1}$ soil & 2.76 & 2.79 & 2.78 \\
\hline $\mathrm{T}_{7}: \mathrm{CaC}_{2} @ 15 \mathrm{~g} \mathrm{~kg}^{-1}$ soil & 2.71 & 2.75 & 2.73 \\
\hline T8: Absolute control & 2.44 & 2.49 & 2.47 \\
\hline Mean & 2.61 & 2.63 & \\
\hline $\mathrm{CD}(0.05)$ & 0.12 & 0.14 & \\
\hline $\mathrm{T}$ & \multicolumn{3}{|c|}{0.09} \\
\hline $\mathrm{Y}$ & \multicolumn{3}{|c|}{ NS } \\
\hline $\mathrm{T} \times \mathrm{Y}$ & \multicolumn{3}{|c|}{0.13} \\
\hline
\end{tabular}

* RD of NPK were applied uniformly to all the treatments except $\mathrm{T}_{8}$ (control)

$\mathrm{PR}=$ Pomegranate Rind MF $=$ Melia Fruits NC $=$ Neem Cake

Combined application of plant derived $\mathrm{N}$-inhibitors with $\mathrm{N}$ fertilizers and organic sources resulted in better quality indices over the control treatment. Similar findings were supported by Bairwa et al. (2009) ${ }^{[4]}$ who reported that application of neem cake along with NPK fertilizer increased the protein content of fruit and total chlorophyll content of the leaves at 30 and 60 DAS in okra. Application of biological inhibitors was also found to improve the chlorophyll content, photosynthetic rate in peanut (Hou et al., 2014). Application of nitrification inhibitors improved the ascorbic acid in the crop. The results in the present expeiment were in agreement with Martinez et al. (2015) ${ }^{[13]}$ and Dong et al. (2016) ${ }^{[6]}$. 
Moreover, application of calcium carbide improved the ascorbic acid and proteins in the crop. Similar findings were reported by Shakar et al., (2017) ${ }^{[18]}$. Lower ascorbic acid in control treatment could be due to reduced carbohydrates production, since vitamin $\mathrm{C}$ is composed of carbohydrates and hence the synthesis of vitamin $\mathrm{C}$ might have been reduced.

\section{Conclusion}

The results of the study revealed that of plant based nitrification inhibitors showed promising results on quality parameters of cauliflower. Treatment of neem cake @ $20 \mathrm{~g} \mathrm{~kg}^{-}$ ${ }^{1}$ soil improved the TSS, ascorbic acid and protein content of the cauliflower during both the years of study and therefore adoption of neem cake as nitrification inhibitor could be a good practice for the farmers.

\section{Acknowledgement}

The authors are grateful to the faculty of Soil Science and Water Managment, Dr. YSP UHF Nauni, Solan for providing financial support to conduct the study. Authors are also thankful to all the persons contributed their precious time during the study period.

Conflict of interest: The authors declare no conflict of interest.

\section{References:}

1. Abbasi MK, Khizar A. Microbial biomass carbon and nitrogen transformations in a loam soil amended with organic-inorganic $\mathrm{N}$ sources and their effect on growth and N-uptake in maize. Ecological Engineering 2012;123:132-139.

2. Abbasi MK, Hina M, Tahir MM. Effect of Azadirachta indica (neem), sodium thiosulphate and calcium chloride on changes in nitrogen transformations and inhibition of nitrification in soil incubated under laboratory conditions. Chemosphere 2011;82:1629-35.

3. Abbasi MK, Shah Z, Adams WA. Effect of the nitrification inhibitor nitrapyrin on the fate of nitrogen applied to a soil incubated under laboratory condition. Jounal of Plant Nutrition and Soil Science 2003;166:513518.

4. Bairwa HL, Shukla AK, Mahawer LN, Kaushik RA, Shu kla KB, Ameta KD, et al. Response of integrated nutrient management on yield, quality and physico-chemical characteristics of okra cv. Arka Anamika. Indian Journal of Horticulture 2009;66:310-14

5. Dinnes DL, Karlen DL, Jaynes DB, Kaspar TC, Hatfield JL, Colvin TS, et al. Nitrogen management strategies to reduce nitrate leaching. Jounal of Agronomy 2002;94:153-171,

6. Dong YJ, He MR, Wang ZL, Chen WF, Hou J, Qiu XK, et al. Effects of new coated release fertilizer on the growth of maize. Journal of soil science and plant nutrition 2016;16:214-21.

7. Fangueiro D, Fernandes A, Coutinho J, Moreira N, Trindade $\mathrm{H}$. Influence of two nitrification inhibitors (DCD and DMPP) on annual ryegrass yield and soil mineral $\mathrm{N}$ dynamics after incorporation with Cattle Slurry. Communications in Soil Science and Plant Analysis 2009;40:3387-3398.

8. Freney JR, Randall PJ, Smith JWB, Hodgkin J, Harrington KJ, Morton TC, et al. Slow release sources of acetylene to inhibit nitrification in soil. Nutrient Cycling in Agroecosystems 2000;56:241-251.
9. Hou J, Dong YJ, Fan ZY. Effects of Coated Urea Amended with Biological Inhibitors on Physiological Characteristics, Yield, and Quality of Peanut. Communications in Soil Science and Plant Analysis 2014;45:896-11.

10. Khalil MI, Gutser R, Schmidhalter U. Effects of urease and nitrification inhibitors added to urea on nitrous oxide emissions from a loess soil. Journal of Plant Nutrition and Soil Science 2009;172:651-660.

11. Kiran U, Patra DD. Medicinal and aromatic plant materials as nitrification inhibitors for augmenting yield and nitrogen uptake of Japanese mint (Mentha arvensis L. Var. Piperascens). Bioresources and Technology 2003;86:267-76.

12. Majumdar D. Suppression of nitrification and $\mathrm{N}_{2} \mathrm{O}$ emission by karanjin - a nitrification inhibitor prepared from karanja (Pongamia glabra Vent.). Chemosphere 2002;47:845-50.

13. Martinez F, Palencia P, Carlos W. Influence of nitrification inhibitor DMPP on yield, fruit quality and SPAD values of strawberry plants. Scientia Horticulturae 2015;185:233-39.

14. Maureen OC, Gerard EM, Carter PE, Lardner R, Sarathchandra U, Burch G, et al. Effect of the nitrification inhibitor dicyandiamide (DCD) on microbial communities in a pasture soil amended with bovine urine. Soil Biology and Biochemistry 2010;42:1425-36.

15. McCarty GW. Mode of action of nitrification inhibitors. Biology and Fertility of Soils 1999;29:1-9.

16. Oyinlola EY, Paul OO, Uyovbisere EO. Effect of neem seed cake and inorganic fertilizer on yield of tomato and soil properties in northern Guinea Savanna of Nigeria. European Journal of Agriculture and Forestry Research 2017;5:1-15.

17. Pereira J, Fangueiro D, Chadwick DR, Misselbrook TH, Coutinho J, Trindade H, et al. Effect of cattle slurry pretreatment by separation and addition of nitrification inhibitors on gaseous emissions and $\mathrm{N}$ dynamics: a laboratory study. Chemosphere 2010;79:620-27.

18. Shakar M, Muhammad Y, Rashid M, Iftikhar A. Effect of coated calcium carbide on growth, yield and some morphophysiological characteristics of cucumber (Cucumis sativus L.). New Zealand Journal of Crop and Horticultural Science 2017;45:251-62.

19. Souri MK. Effectiveness of chloride compared to 3, 4dimethylpyrazole phosphate on nitrification inhibition in soil. Communications in Soil Science and Plant Analysis 2010;41:1769-78.

20. Subbarao GV, Ito O, Sahrawat KL, Berry WL, Nakahara $\mathrm{K}$, Ishikawa $\mathrm{T}$, et al. Scope and strategies for regulation of nitrification in agricultural systems - challenges and opportunities. Critical Reviews in Plant Sciences 2006;25:303-335.

21. Toselli M, Baldi E, Sorrenti G, Quartieri M, Marangoni B. Evaluation of the effectiveness of soil-applied plant derivatives of Meliaceae species on nitrogen availability to peach trees. Scientia Horticulturae 2010;124:183-88.

22. Warneke S, Schipper LA, Bruesewitz DA, McDonald I, Cameron S. Rates, controls and potential adverse effects of nitrate removal in a denitrification bed. Ecological Engineering 2011;37:511-22.

23. Zaman M, Saggar S, Blennerhassett JD, Singh J. Effect of urease and nitrification inhibitors on $\mathrm{N}$ transformation, gaseous emissions of ammonia and nitrous oxide, pasture 
yield and $\mathrm{N}$ uptake in grazed pasture system. Soil Biology and Biochemistry 2009;41:1270-80.

24. Zhang M, Fan CH, Li QL, Li YY, Zhu Z, Xiong Q, et al. A 2-yr field assessment of the effects of chemical and biological nitrification inhibitors on nitrous oxide emissions and nitrogen use efficiency in an intensively managed vegetable cropping system. Agriculture, Ecosystems and Environment 2015;201:43-50. 